\title{
Correlation between Demographic Status and Nutritional Status against the Occurrence of Anemia toward Female Students in SMP Negeri 3 Kediri
}

\author{
Lumastari Ajeng Wijayanti, Eny Sendra*, Ratih Novitasari, Tanti Dwi Pujaningsih \\ Health Polytechnic of Ministry of Health, Malang, East Java, Indonesia \\ enysendra@ymail.com
}

\begin{abstract}
This research was conducted in order to investigate the correlation between demographic status and nutritional status against the occurrence of anemia towards female students in Junior High School (SMP Negeri) 3 Kediri. This research used cross sectional design. The population was 194 respondents and the sample was 54 respondents which are taken by using simple random sampling technique. Independent variable in this research was demographic status that was measured by questionnaire and nutritional status that was measured based on Body Mass Index (BMI). Meanwhile, dependent variable in this research was the occurrence of anemia that was measured by using spectrophotometry. Data analysis used Fisher's Exact test and Two-Sample Kolmogorov-Smirnov test $(\alpha=0,05)$. Result of Fisher's Exact test was obtained that $p$ value $=1,000>0,05$, which meant that there was no significant correlation between demographic status and the occurrence of anemia. Meanwhile, result of Two-Sample Kolmogorov-Smirnov test was obtained that $\mathrm{p}$ value = $0,017<0,05$, which meant that there was a significant correlation between nutritional status and the occurrence of anemia. However, the researchers suggest that school can coordinate with Public Health Center through government's program, which is School Health Effort (UKS (Usaha Kesehatan Sekolah)) so that it can monitor the nutritional intake for the female students by periodically examining hemoglobin, distributing Fe tablets, and teaching them how to take and drink Fe tablets properly.
\end{abstract}

Keywords : Anemia, Demographic Status, Nutritional Status, Female

Received December, 25, 2019; Revised January 24, 2020; Accepted February 15, 2020 


\section{STRADA Jurnal Ilmiah Kesehatan}

DOI: $10.30994 /$ sjik.v9i1.274

ISSN: 2252-3847 (print); 2614-350X (online)

Vol.9 No.1. May 2020. Page.111-118

\section{INTRODUCTION}

Population in Indonesia recently increases more. More than two hundred millions of population who are noted, there are about 37,3 millions of people who are alive below the poverty line. Half from the household total consume food in less than daily needs and more than one hundreds of people have risk against various malnutrition problems. Imbalance in food nutrition that is consumed can cause disruption of the growth of organs and body tissues, weak immune system against disease, and the decrease of activity and work productivity. Furthermore, living environment will affect low food consumption and nutrition levels which are obtained (Andriani and Wirjatmadi, 2012).

Generally, nutrition problems are found more in Indonesia, while, in developing countries are Protein Energy Malnutrition (PEM) problem, Iron Deficiency Anemia problem, Iodine Deficiency Disorders (IDD) problems, Vitamin A Deficiency problems, and obesity problem, especially in urban area. Besides, it is assumed that there is another micro nutrition problem, such as Zinc deficiency which until recently, it has been unknown (Supariasa, 2012).

Nutritional anemia is a condition of blood hemoglobin level that is lower than normal as the effect of tissue inability for the formation of red blood cell in its production so that it can defend hemoglobin level in normal condition. This nutritional anemia case is very often found in Indonesia and it can be suffered by all people no matter how old they are (Andriani and Wirjatmadi, 2012).

Anemia problem in proportion of people's age $\geq 1$ year in Indonesia reaches $21,7 \%$. Based on age classification, the percentage of anemia in age group of 5-14 years old reaches $26,4 \%$. The percentage of the occurrence of anemia in this age is higher rather than in age group of 15-24 years old, which only reaches $18,4 \%$. Besides, the percentage of the occurrence of anemia in rural area is higher, which is $22,8 \%$, rather than in urban area, which is $20,8 \%$ (Riset Kesehatan Dasar, 2013).

From data that was obtained by researchers through preliminary study in Public Health Office in Kediri City, East Java Province, Indonesia on 11th October 2018, had been conducted a measurement of hemoglobin level against female students who were 10-18 years old in Junior High School (SMP) and Senior High School (SMA) in Kediri City in order to survey the students' $\mathrm{Hb}$ (hemoglobin). Among 500 samples which were taken randomly, it was known that students who suffered from anemia were 48 students or $9,6 \%$, which the highest occurrence was suffered by female students in SMP Negeri 3 Kediri (Dinas Kesehatan Kota Kediri (Public Health Office in Kediri City), 2018).

According to conducted research by Permaesih and Herman (2005) regarding factors in correlating with anemia toward teenagers stated that one of factors that influenced it was socioeconomic and demographic factor. Meanwhile, another conducted study by Setyawati and Setyowati (2015) regarding the characteristic of nutrition in urban female adolescents and rural female adolescents in Central Java Province showed that the average of nutritional status toward female adolescents who lived in urban area was lower rather than nutritional status toward female adolescents who lived in rural area.

In conducted study by Yunarsih and Antono (2014) which titled "Hubungan Pola Menstruasi dengan Kejadian Anemia Pada Remaja Putri Kelas VII SMPN 6 Kediri” (Correlation between Menstrual Pattern and the Occurrence of Anemia toward Seventh Grade Female Students in SMPN 6 Kediri) was obtained result of hemoglobin level on the seventh grade female students in SMPN 6 Kediri was around 9,0-17,0 g/dl and the total occurrence of anemia was 11 respondents or $27 \%$ from total of all respondents (41 respondents). Result of 


\section{STRADA Jurnal Ilmiah Kesehatan}

DOI: $10.30994 /$ sjik.v9i1.274

this research was obtained among 7 of 11 respondents who suffered from anemia had low Body Mass Index (BMI) and this could show that nutritional status was also one of causes in occurring anemia toward female adolescents. However, it was in line with conducted research by Agustina and Fridayanti (2017) regarding risk determinant of the occurrence of anemia toward female adolescents, which was obtained that there was a significant correlation between anthropometric nutritional status and the occurrence of anemia toward female adolescents.

In addition, result of conducted research by Rohmawati (2017) that titled "Hubungan Status Gizi dengan Kadar Hemoglobin pada Remaja Putri Usia 15-17 Tahun di SMK Dr. Wahidin Sawahan dan SMA Muhammadiyah Kabupaten Nganjuk Tahun 2017" (Correlation between Nutritional Status and Hemoglobin Level toward 15-17 years old of Female Students in SMK Dr. Wahidin Sawahan and SMA Muhammadiyah in Nganjuk District in 2017) with respondents in 59 students. Moreover, it was concluded that there was a significant correlation between nutritional status and hemoglobin level toward 15-17 years old of Female Students in SMK Dr. Wahidin Sawahan and SMA Muhammadiyah in Nganjuk District in 2017.

Thus, according to the explanation above, it could be concluded that there were many female students who suffered from iron deficiency anemia, and they lived in either rural area or urban area due to their dietary habit and low nutritional status.

\section{METHODS}

This research used cross sectional research. The populations in this research were all of seventh grade students in SMP Negeri 3 Kediri, and they were 194 students. The samples in this research were 54 respondents which were collected by using simple random sampling technique. Independent variable in this research was demographic status that was measured by using questionnaire and the nutritional status was measured based on Body Mass Index (BMI) and dependent variable, which was the occurrence of anemia that was measured by using spectrophotometry. Meanwhile, data analysis in this research used Fisher's Exact test and Two-Sample Kolmogorov-Smirnov test $(\alpha=0,05)$.

\section{RESULTS}

\section{General Data}

Based on result of research data, it was obtained that most of respondents $(53,7 \%)$ were 13 years old, almost half of them $(38,8 \%)$ had total of family member in 4 persons and almost half of them $(46,3 \%)$ had parents who worked as private employees.

Respondent's characteristics based on food consumption in this research were most of the respondents $(68,5 \%)$ had eating frequency in $3 x /$ day and most of them $(68,5 \%)$ did not have any food that must be avoided, but some of the respondents $(20,3 \%)$ avoided to eat vegetables (11 respondents), meanwhile, each of some respondents $(5,6 \%)$ avoided to eat egg and sea food (3 respondents). From consumption of breakfast food side, most of the respondents $(62,6 \%)$ always had breakfast every day, some of them $(20,4 \%)$ confessed to have breakfast sometimes in 2-3 times in a week (11 respondents), and the others $(18,5 \%)$ confessed to have breakfast rarely by the reason of having no time, no breakfast available, and no accustoming to have breakfast. Among 10 respondents who never had breakfast, the 6 of them lived in Kediri District.

Based on types of snacks which were bought by respondents, almost half of them $(48,1 \%)$ confessed to buy snack/cake. Almost half of them $(35,2 \%)$ used their pocket 
money to buy snacks, such as pentol/batagor/otak-otak which were sold in their school. Some of the respondents $(14,8 \%)$ bought soft drink/ ice cream. Meanwhile, some of other respondents $(1,9 \%)$ bought snacks, such as crispy tofu and egg macaroni (makaroni telur (maklor)).

\section{Particular Data}

a. Demographic Status

Table 1 Distribution of Respondents Based on Demographic Status

\begin{tabular}{cccc} 
Number & Residence & Total (Person) & Percentage (\%) \\
\hline 1 & City & 27 & 50,0 \\
2 & District & 27 & 50,0 \\
\hline \multicolumn{2}{c}{ Total } & 54 & 100,0 \\
\hline
\end{tabular}

Based on notes in table 1 above, it was known that among the total of respondents who were 54 respondents, half of them $(50,0 \%)$ had lived in City area and there were 27 respondents. Meanwhile, other half of them had lived in District area and there were 27 respondents.

b. Nutritional Status

Table 2 Distribution of Respondents Based on Nutritional Status

\begin{tabular}{|c|c|c|c|}
\hline Number & $\begin{array}{c}\text { Nutritional } \\
\text { Status }\end{array}$ & Total (Person) & Percentage $(\%)$ \\
\hline 1 & Normal & 21 & 38,9 \\
\hline 2 & Fat & 9 & 16,7 \\
\hline 3 & Thin & 24 & 44,4 \\
\hline \multicolumn{2}{|c|}{ Total } & 54 & 100,0 \\
\hline
\end{tabular}

Based on Table 2 above, it was known that among the total of respondents who were 54 respondents, almost half of them $(44,4 \%)$ who were 24 respondents had thin nutritional status. Meanwhile, almost half of them $(38,9 \%)$ who were 21 respondents had normal nutritional status. Other some of them $(16,7 \%)$ who were 9 respondents had fat nutritional status.

c. The occurrence of Anemia

Table 3 Distribution of Respondents Based on the Occurrence of Anemia

\begin{tabular}{cccc}
\hline Number & $\begin{array}{c}\text { The Occurrence of } \\
\text { Anemia }\end{array}$ & Total (Person) & Percentage (\%) \\
\hline 1 & Not anemia & 47 & 87,1 \\
2 & Anemia & 7 & 12,9 \\
\hline & Total & 54 & 100,0 \\
\hline
\end{tabular}

Based on table 3 above, it was known that among total of respondents who were 54 respondents, almost all of them $(87,1 \%)$ had hemoglobin level in category of not anemia and there were 47 respondents. Meanwhile, some respondents $(12,9 \%)$ had hemoglobin level in category of anemia and there were 7 respondents. 
d. Correlation between Demographic Status and the Occurrence of Anemia

Table 4 Correlation between Demographic Status and the Occurrence of Anemia

\begin{tabular}{cccccc}
\hline \multirow{2}{*}{$\begin{array}{c}\text { Demographic } \\
\text { Status }\end{array}$} & \multicolumn{4}{c}{ The Occurrence of Anemia } & \multirow{2}{*}{ P Value } \\
\cline { 2 - 4 } & f & \% & f & Not Anemia & \\
\hline District & 4 & 14,8 & 23 & 85,2 & 1,000 \\
City & 3 & 11,1 & 24 & 88,9 & \\
Total & 7 & 12,9 & 47 & 87,1 & \\
\hline
\end{tabular}

$\mathrm{P}$ value was calculated based on Fisher's Exact Test.

Based on table 4 above, it was known that among 27 respondents who had lived in Kediri City, almost all respondents $(88,9 \%)$ who were 24 respondents did not suffer from anemia and the other 27 respondents who had lived in Kediri District, almost all of them $(85,2 \%)$ who were 23 respondents did not suffer from anemia. Distribution of the data showed that female adolescents who lived in area of Kediri City were lower to suffer from anemia rather than female adolescents who lived in area of Kediri District.

From the result of Fisher's Exact Test, it was obtained that $p$ value $=1,000>$ 0,05 , thus, $\mathrm{H}_{0}$ was accepted, which meant that there was no significant correlation between demographic status and the occurrence of anemia toward female students in Junior High School (SMP Negeri) of 3 Kediri.

e. Correlation between Nutritional Status and the Occurrence of Anemia

Table 5 Correlation between Nutritional Status and the Occurrence of Anemia

\begin{tabular}{cccccc}
\hline \multirow{2}{*}{$\begin{array}{c}\text { Nutritional } \\
\text { Status }\end{array}$} & \multicolumn{4}{c}{ The Occurrence of Anemia } & \multirow{2}{*}{ P Value } \\
\cline { 2 - 4 } & $\mathbf{f}$ & $\mathbf{\%}$ & $\mathbf{f}$ & $\mathbf{\%}$ & \\
\hline Thin & 0 & 0 & 24 & 100 & 0,017 \\
Normal & 6 & 28,6 & 15 & 71,4 & \\
Fat & 1 & 11,1 & 8 & 88,9 & \\
Total & 7 & 12,9 & 47 & 87,1 & \\
\hline P value was calculated based on Two-Sample Kolmogorov-Smirnov Test.
\end{tabular}

Based on Table 5 above, it showed that among 21 respondents who had normal nutritional status, most of them $(71,4 \%)$ who were 15 respondents did not suffer from anemia. Meanwhile, among 9 respondents who had fat nutritional status, almost all of them $(88,9 \%)$ who were 8 respondents did not suffer from anemia. Meanwhile, among 24 respondents who had thin nutritional status $(100,0 \%)$, all of them did not suffer from anemia. However, distribution of the data showed that female students who had normal nutritional status were easier to suffer from anemia rather than female students who had either fat or thin nutritional status.

From the result of Two-Sample Kolmogorov-Smirnov Test, it was obtained that $\mathrm{p}$ value $=0,017<0,05$, thus, $\mathrm{H}_{1}$ was accepted, which meant that there was a significant correlation between nutritional status and the occurrence of anemia toward female students in Junior High School (SMP Negeri) of 3 Kediri. 


\section{DISCUSSION}

1. Correlation between Demographic Status and the Occurrence of Anemia toward Female Students in SMP Negeri 3 Kediri

Result of this research showed that among 27 respondents who lived in Kediri City, almost all of them $(88,9 \%)$ who were 24 respondents did not suffer from anemia and the other 27 respondents who lived in Kediri District, almost all of them $(85,2 \%)$ who were 23 respondents did not suffer from anemia. Distribution of data showed that female students who lived in area of Kediri City were lower to suffer from Anemia rather than female students who lived in Kediri District.

Result of chi-square test, it was obtained that $p$ value in chi-square column did not qualify the requirement because there was still expected count cell value in 50\% in Table $2 \times 2$. Thus, it was used further test, which was Fisher's Exact Test and it was obtained $\mathrm{p}$ value $=1,000>0,05$, hence, $\mathrm{H}_{0}$ was accepted, which meant that there was no significant correlation between demographic status and the occurrence of anemia toward female students in SMP Negeri 3 Kediri.

According to Irianto and Friyatmi (2016), in demographic process, they stated that mortality was one of factors in influencing the correlation among variable of individual level, variable of household level, and variable of society condition. In variable of individual level, it correlated with parents' productivity, acceptable norms, and attitudes. Furthermore, there were three elements that determined productivity of household members. Those elements were education level, health, and time. Female adolescents' health level were also influenced by time that was provided by their mother to give good food, clean the house, and prevent several diseases such as implementing Clean and Healthy Life Behavior (perilaku hidup bersih dan sehat (PHBS)).

Result of this research supported a result of conducted research by Bharati Vidyapeeth that titled Prevalence of Anemia among Urban and Rural Adolescents (2016). It showed that there was no significant difference between female adolescents who lived in urban area and rural area against the occurrence of anemia.

Based on result of the research and statement above, it could be concluded that demographic status based on location of residence could not be become the only benchmark to investigate the occurrence of anemia because female adolescents were not only life and having socialization in home environment, but also in school environment. Knowledge about nutrition that was obtained from school, occupation, adequate parents' income, and the fulfillment of adequate nutrition could influence female adolescents' health status, thus, they could be prevented from anemia disease.

\section{Correlation between Nutritional Status and the Occurrence of Anemia toward} Female Students in SMP Negeri 3 Kediri

Result of this research showed that among 21 respondents who had normal nutritional status, most of them $(71,4 \%)$ who were 15 respondents did not suffer from anemia. Among 8 respondents who had fat nutritional status, almost all of them $(87,5 \%)$ who were 7 respondents did not suffer from anemia. Meanwhile, the 24 respondents who had thin nutritional status, all of them $(100,0 \%)$ did not suffer from anemia. Distribution of the data (questionnaire) showed that female students who had normal nutritional status were easier to suffer from anemia rather than female students who had either fat or thin nutritional status. 


\section{STRADA Jurnal Ilmiah Kesehatan}

DOI: $10.30994 /$ sjik.v9i1.274

Result of chi-square was obtained that $\mathrm{p}$ value in chi-square column did not qualify the requirements because there was still expected count cell value in $50 \%$ in table $2 \times 3$. Thus, it was used further test, which was Two-Sample Kolmogorov-Smirnov Test and it was obtained $\mathrm{p}$ value $=0,017<0,05$ and $\mathrm{H}_{1}$ was accepted. It meant that there was a significant correlation between nutritional status and the occurrence of anemia toward female students in SMP Negeri 3 Kediri.

Result of this research supported a result of conducted research by Wibowo (2013). He stated that there was a significant correlation between nutritional status and the occurrence of anemia. According to Andriani (2012), she stated that female adolescents needed more iron $(\mathrm{Fe})$ rather than male adolescents. Food that contained more iron were such as green vegetables, liver, red meat (beef, goat, lamb) white meat (chicken, fish), and beans. If female adolescents were lack of iron $(\mathrm{Fe})$, they would suffer from anemia and if it got worse, it could threaten their lives. If anemia persisted for long time, it would cause disruption on the menstrual cycle due to imbalance production of estrogen and progesterone hormones.

Based on the explanation above, the researchers argued that most of female students in SMP Negeri 3 Kediri who suffered from anemia were respondent who had normal nutritional status. This could be correlated with the factor of food intake, which most of them who had normal nutritional status had adequate eating frequency that was $3 x /$ day. Nevertheless, some of them who were 6 respondents prevented to eat green vegetables by the reason of mostly disliking bitter taste from the vegetables and it was unpleasant taste. Hence, the Fe intake that was consumed by female adolescents had not been fulfilled. Besides consuming vegetables, the female adolescents should consume various types of food that contained iron due to in order to fulfill nutrition needs that could not be only in one type of food, but it needed iron intake from various types of food.

\section{CONCLUSION}

From this research, it could be concluded that in demographic status, respondents who had lived in Kediri City had average of distance in $\pm 4 \mathrm{~km}$ for being to school and respondents who had lived in Kediri District had average of distance in $\pm 12 \mathrm{~km}$ for being to school. Furthermore, most of female students in SMP Negeri 3 Kediri had thin nutritional status and the occurrence of anemia toward female students in SMP Negeri 3 Kediri, almost all of them had hemoglobin level in category of not anemia.

Hence, results of this research were:

1. There was no significant correlation between demographic status and the occurrence of anemia toward female students in SMP Negeri 3 Kediri.

2. There was a significant correlation between nutritional status and the occurrence of anemia toward female students in SMP Negeri 3 Kediri.

Therefore, the researchers suggested for government through Public Health Office was in order to monitor School Health Effort (UKS (Usaha Kesehatan Sekolah)) so that they could evaluate the giving of tablet of blood booster toward female students. Besides, the Public Health Office should cooperate with schools to do check hemoglobin levels regularly and distribute Fe tablets to be taken and drunk together so that the female students could avoid the danger of nutritional anemia.

All in all, for further research, the researchers suggested to select different school which located in City and in District area. 


\section{REFERENCES}

Andriani, M. and Wirjatmadi, B. (2012). Pengantar Gizi Masyarakat. Jakarta: Kencana.

Agustina, Ely E. and Fridayanti W. (2017). Determinan Risiko Kejadian Anemia Pada Remaja Putri Berdasarkan Jenjang Pendidikan di Kabupaten Kebumen. Jurnal Ilmiah Kebidanan, Vol. 8 No. 1 pp. 57-70. Available at: http://www.akbidylpp.ac.id/ojs/index.php/Prada.

Irianto, A. and Friyatmi. (2016). Demografi dan Kependudukan. Jakarta: Kencana.

Permaesih, D. and Herman, S. (2005). 'Faktor-faktor yang Mempengaruhi Anemia Pada Remaja', Badan Litbangkes, p. 162. Available at: https://www.neliti.com/publications/20280/faktor-faktor-yang-mempengaruhianemia-pada-remaja

Rohmawati, N. (2017). 'Hubungan Status Gizi dengan Kadar Hemoglobin Pada Remaja Putri Usia 15-17 Tahun di SMK Dr. Wahidin Sawahan dan SMA Muhammadiyah Kabupaten Nganjuk Tahun 2017', Poltekkes Kemenkes Malang.

Riset Kesehatan Dasar. (2013). http://www.depkes.go.id/resources/download/general/Hasil\%20Riskesdas\%202013.p df accessed on $11^{\text {th }}$ September 2018 in 22.15 WIB.

Setyawati, Vilda A. and Setyowati, M. (2015). Karakteristik Gizi Remaja Putri Urban dan Rural di Provinsi Jawa Tengah. Jurnal Kesehatan Masyarakat. Available at: https://journal.unnes.ac.id/nju/index.php/kemas.

Supariasa, I. D. N. (2012). Penilaian Status Gizi. Jakarta: EGC.

Vidyapeeth, Bharati. (2016). 'Prevalence of Anemia Among Urban and Rural Adolescents'. International Journal of Applied Research 2016. Available at:https://www.researchgate.net/publication/305264155.

Wibowo, C. D. T., Notoatmojo, H. and Rohmani, A. (2013). 'Hubungan Antara Status Gizi dengan Anemia Pada Remaja Putri di Sekolah Menengah Pertama Muhammadiyah 3 Semarang', Jurnal Kedokteran Muhammadiyah, 1, p. 1. Available at: https://prosiding.unimus.ac.id/index.php/kedokteran/article/view/1298.

Yunarsih and Antono, S. D. (2014). 'Hubungan Pola Menstruasi dengan Kejadian Anemia Pada Remaja Putri Kelas VII SMPN 6 Kediri', Jurnal Ilmu Kesehatan, 3, p. 25. Available at: https://ejurnaladhkdr.com/index.php/jik/article/view/42 